\title{
Analysis of The Concept and Attraction and The Development od Tge "Langen Mandra Wanara" Art from Yogyakarta
}

\author{
Nofansyah ${ }^{1 *}$, Redyanto Noor ${ }^{2}$ \\ ${ }^{1}$ Master of Literature, Diponegoro University, Semarang, Indonesia \\ ${ }^{2}$ Master of Literature, Diponegoro University, Semarang, Indonesia
}

\begin{abstract}
Langen Mandra Wanara is a Javanese dance-drama genre that tells Ramayana story taking place in the Kepatihan complex. It has become a very popular performing art and has been widely studied by the people of Yogyakarta. This study aimed to discuss the concept, attractiveness and development of the "Langen Mandra Wanara" art. The study used a descriptive analysis method. In this research, the data was the art of Langen Mandra Wanara from Yogyakarta, which was obtained from various secondary sources, including previous research journals, internet sites, books and documentation. The results showed that Langen Mandra Wanara has a basic concept called the Joged Mataram philosophy in dancing. At the beginning of its development, the art performance was marked by the appearance of a large number of wanara (monkey) dancers. Unlike other arts, Langen Mandra Wanara basically aims to provide entertainment to the public for free. In its development, Langen Mandra Wanara's performance declined due to the influence of the Dutch colonial economic situation. Currently, Langen Mandra Wanara shows tend to be concise, performed much shorter, and involve fewer players. Thus, the production cost of court performing arts can be reduced much cheaper than before.
\end{abstract}

\section{INTRODUCTION}

Humans and culture are inseparable; together, they make up life. Humans who assemble themselves into socio-cultural units become society. Human society gives birth to, creates, grows and develops culture: there is no human being without culture, and conversely, there is no culture without humans; there is no society without culture, there is no culture without society. Culture is the creation of humans in society. Human awareness of their experiences encourages them to formulate formulations, limitations, definitions, and theories about activities called culture, the conception of culture. Taylor in Kistanto (2015) [1] compiles the concept of culture, which he formulates briefly as follows. "Culture or Civilization ... is a complex that includes knowledge, beliefs, arts, morals, laws, customs, and many other abilities and habits that humans acquire as members of society. " (Culture or Civilization is

*Corresponding Author: Nofansyah888@gmail.com 
a complex unit that includes science, belief, art, morals, law, customs, and many other abilities and habits acquired by humans as members of society).

National culture is the norms, behaviour, beliefs, customs, and values shared by residents of a sovereign country (for example, the national culture of China or Canada). It refers to specific characteristics such as language, religion, ethnic and racial identity, cultural history and traditions. A set of unique beliefs, values and assumptions that members of a national group generally hold. National cultural differences can be expressed as values on several dimensions: power distance, masculinity-femininity, individualism-collectivism, and uncertainty avoidance. These dimensions can be calculated and provide a country-specific profile. It is important to note that : (a) the scores on this dimension are statistical averages, with considerable individual variance and overlap with other national cultures; and (b) national profiles help predict behaviour but should not be used to judge or stereotype others [2]

One of the cities in Indonesia with a variety of exciting cultures and arts is the city of Yogyakarta. Yogyakarta City is the capital of Yogyakarta Province and is the only level II region with City status and 4 other level II regions with Regency status. In Yogyakarta, many traditional dances are still regularly performed at various events or places.

The traditional dances removed from their natural media and brought to the stage are no less numerous than the figures, dance forms, clothes, and music. This is when traditional dances begin to be forgotten, lose quality and disappear and take a form that the community in the environment cannot realize. Dance is a factor that brings people closer to each other, teaches friendship, friendship, compassion and respect and fosters a sense of national unity and togetherness, and has an important place in human life. Dance is a source of joy, happiness and life. It is like a light that frees man from bad thoughts and enlightens and strengthens his morals. The dance performance makes man love life, makes him happy and gives him the strength to live. [3]

Langen Mandra Wanara is a Javanese dance-drama created in the 1980 s by KPH Yudonegoro III. The background story in this dance drama is the Rayamayana story that takes place in the kepatihan complex. The way to dance is with the dancer sitting on his feet, or the joged jengkeng movement (sitting on the leg), while when dancing, there is a dialogue called macapat. KPH Yodunegoro III is the noble son-in-law of Sri Sultan Hamengku Buwono VII who has the position of Patih Dalem with the title KPAA Danurejo VII. When he was young, KPH Yudonegoro III was pleased to see a traditional dance drama called Srandul with the backdrop of the Serat Menak story. However, KPH Yudonegoro II, the parent of KPH Yudonegoro III, does not seem very happy if his son focuses too much time on traditional dance drama arts. KPH Yudonegoro II then suggested that KPH Yudonegoro III should present a performance with palace certificates and take the main story from the history of Ramayana.

$\mathrm{KPH}$ Yudonegoro III still obeys the wishes of his masters, but he is not happy with the strict regulations at the palace regarding traditional dance drama performances that he likes. Without prejudice to a prohibition within the palace, KPH Yudonegoro III then imitates Langendriya's earlier performing arts. By referring to the Langendriya presentation concept and pattern combined with the folk art presentation pattern, the Langen Mandra Wanara dance drama appears uniquely. Langen Mandra Wanara consists of three words, namely Langen, which means entertainment or fun, Mandra means many, and Wanara is a monkey. At the beginning of its development, the Langen Mandra Wanara performance was marked by the appearance of a large number of wanara (monkey) dancers. Unlike other arts displayed in the royal environment, Langen Mandra Wanara aims to provide entertainment to the public for free. 
As stated by Pace and Faules in Jaeni (2014) [4] that communication is not just a tool to describe thoughts, but it is thought and knowledge. Performing arts communication is not just communication as a practical action but higher as a pragmatic action and even an ideal action. In the performing arts, it also shows an effort to make both the audience and the performers aware that the two are interrelated and interconnected but conceptually distant from the existence of reality, namely drama. Based on the background description above, this article will discuss the Analysis of Concepts and Attraction and the Development of the Art of "Langen Mandra Wanara" from Yogyakarta.

\section{PROBLEM AND FORMULATION}

This research tries to answer a question related to the results of the analysis of concepts and attraction and the development of the art of "Langen Mandra Wanara" from Yogyakarta include:

a. Concepts and Attraction of Langen Mandra Wanara art

Langen Mandra Wanara is a Javanese dance drama created in the 1980s by KPH Yudonegoro III. The background story in this dance drama is the Rayamayana story that takes place in the kepatihan complex.

b. The development of Langen Mandra Wanara

Langen Mandra Wanara has become a very popular performing art and has been widely studied by the people of Yogyakarta, so that during the first 30 years of the 20th century, Langen Mandra Wanara experienced the peak of its development.

\section{THEORY AND METHOD}

The research studies about the initial concept of culture, which originated from primitive societies, contained a practical side as a source of power intended to influence modern ideas and actions. Constructing a relationship between what uncultured ancient humans thought and did and what cultured modern humans thought and did is not a matter of inapplicable theoretical science because this question raises the question of how far the view and modern behaviour are based on the most plausible foundation of modern science. [1].

The research method is a scientific way to obtain data with specific purposes and uses [5]. A method is a primary method used by researchers to achieve goals. Thus, the method is chosen based on the consideration of the suitability of the object to be studied. In the method, there are techniques and approaches. So, the literary research method will contain the scientific approach (point of view) and analysis techniques used. Accurate research methods, of course, will apply appropriate research approaches and techniques (Endraswara, 2008).

This study uses the descriptive analysis method. According to Ratna (2008: 39), the descriptive analysis method is used by analyzing and deciphering data to describe the state of the object under study, which is the centre of research attention. This research method uses a qualitative approach. According to Strauss and Corbin (Cresswell j, 1998: 24), qualitative research produces findings that cannot be achieved by statistical or measurement measures. This type of research can be used to research social life, history, behaviour, and others. The data used are primary data by conducting interviews with artists and institutions that oversee the arts of Langen Mandra Wanara. Researchers also use secondary data from various sources such as books, documentation, previous research journals, and internet sites. Furthermore, doing analysis and literature study of Langen Mandra Wanara art. 


\section{RESULT AND DISCUSSION}

\subsection{Concept and Attraction of Langen Mandra Wanara Art}

Langen Langen Mandra Wanara has a variety of dance movements performed in the joged jengkeng position, namely by squatting using your knees as support in dance movements. Slightly different from Langendriya, who even though they both use joged jengkeng, the jengku (knee) of the dancer Langen Mandra Wanara is in a position to touch the floor. This technique was deliberately created not to match the Wayang Wong dance drama at the Yogyakarta Palace, performed while standing.

The dialogue used in Langen Mandra Wanara uses the macapat song performed in the form of Lampah Sekar Gendhing and Rambangan. The musical accompaniment of Langen Mandra Wanara with the help of the gamelan musical instrument barrel slendro and pelog barrel with pieces showing the various scenes played. The background of the story is the epic Ramayana. Ordinary lapon this dance drama displays; Sinta Ilang, Subali Lena, Anggada Duta, Senggana Duta, Wibisana Tundhung, Wibisana Balik, Rama Tambak, Kumbakarnaatuh, and so on. In addition, the play that was also performed was Lokapala, with the plays Sumantri Ngenger and Bedhahing Lokapala.

The attractiveness of Langen Mandra Wanara is the integration of the great royal values with popular values. This can be seen from the dynamic and orderly way of performing dance dramas, subtle dialogue expressions and full of literary value, but still controlled and containing an urakan element displayed during senggakan in the form of spontaneous bursts of words to interrupt the song dialogue. The keplok alok element in the Langen Mandra Wanara show is presented with spontaneous applause at certain times, especially during relaxed, cheerful, and joyful scenes. Langen Mandra Wanara's populist spirit is shown in such a thick manner that it sometimes appears impudent and harsh.

In general, Langen Mandra Wanara dancers 'dress refers to the Wayang Wong dancers' dress. Male dancers use headbands in the form of tepen, necklaces, shoulder straps, kaweng, timang dictionaries, keris, sampur, jarik, and pennant pants. Female dancers use semekan, slepe, sampur, bun Kondhe, ceplok jebehan, sangsangan, and sengkang. The application of Langen Mandra Wanara makeup also refers to Wayang Wong makeup.

The characters in Langen Mandra Wanara are broadly characterized by dashing sons, gentle sons, female characters, giant characters, and monkey characters. There is also the role of the Dalang, who is in charge of mastering the storyline, understanding pieces, and animating the course of each scene.

\subsection{The Development of Langen Mandra Wanara}

Initially, the practice and performance of Langen Mandra Wanara were held in the courtyard of Dalem Yudanegaran, the residence of KPH Yudonegoro III. However, since he was appointed as Patih Dalem with KPAA Danurejo VII, all of Langen Mandra Wanara's performance activities have moved to Kepatihan Danurejan. The show received tremendous attention from the broader community so that it gave rise to other groups that contributed to the growth and development of Langen Mandra Wanara, such as in the villages of Notoyudan, Condronegaran, Kumendaman, Sosrowijayan, Tegalgendu, and the Mardi Guna Association under the leadership of KRT Jayadipura. Langen Mandra Wanara so that the area of Bantul Regency such as Sembungan, Sawahan, and Pundong is getting wider. Even in Sleman Regency, in Morangan Village, the community has developed an art similar to Langen Mandra Wanara as Langen Purba Wanara. 
According to Prabhawati (2020) [6], the peak of the Langen Mandra Wanara dance was in the 20th century. Where almost everywhere can be found this art. However, since the 1930s Langen Mandra Wanara's development began to experience stagnation. The Langen Mandra Wanara dance drama art is rarely performed in front of the public. This was due to various factors, including the increasing public attention to Wayang Wong, which was being promoted by Sri Sultan Hamengkubuwono VIII at that time. The economy had decreased, which resulted in a significant reduction in support for the arts sector. Especially during the Japanese occupation in which Sri Sultan Hamengkubuwono IX removed the position of Pepatih Dalem. Due to the change in the function of Dalem Kepatihan, the Langen Mandra Wanara training activities there were stopped entirely. The fate of this art then lies entirely in the arts groups that exist in society.

Langen Mandra Wanara performances have increased in frequency because they were helped by the economic situation of the Netherlands at that time and also by paying attention to the attention of the Wayang Wong community, the version of the Yogyakarta palace. The condition of Java as a Dutch colonial region experienced a great economic depression which began in the late 1920s. Other colonies throughout Indonesia also improved this condition due to the economic crisis that never ended [7]. However, this condition is inversely proportional to the life of the court performing arts. Although the depression significantly reduced most of the Sultan's income from sugar cane plantations, performing arts such as the Wayang Wong keraton continued, and major performances were still staged until 1939. Massive performances such as Wayang Wong at very high costs were exhibits to demonstrate the wealth and greatness of the Sultan

This also implies that the Sultan has a higher status authority than his people. When Sultan Hamengku Buwana IX decided to join the Unitary State of the Republic of Indonesia, the Sultanate of Yogyakarta did not need state ceremonial activities such as holding a lavish Wayang Wong performance. Palace performances during Sultan Hamengku Buwana IX and Sultan Hamengku Buwana X tended to be brief and staged much shorter, and involved fewer players. Thus, the production cost of court performing arts can be reduced much cheaper than before. The unification of the Yogyakarta Sultanate into the Unitary State of the Republic of Indonesia also had a significant effect on the survival of Langen Mandra Wanara. Although it does not change the subject matter of the story and also the dialogue, Langen Mandra Wanara, at this time, is displayed in a shorter time and a denser message. Dance presentation is performed flexibly by joged jengkeng or joged ngadeg (standing position).

In dancing, Langen Mandra Wanara also has a fundamental principle called the Joged Mataram philosophy. Joged Mataram has a significant meaning and psychological basis in Javanese dance style Yogyakarta such as in Langen Mandra Wanara. This concept was introduced more openly by Gusti Bandara Pangeran Harya Soeryobrongto, son of Sri Sultan Hamengku Buwana VIII, and he was also an expert in classical dance in the Yogyakarta style in 1968. The four basic principles of the Joged Mataram philosophical concept are sawiji (total concentration but without having to cause chaos or tension in the soul), greged (spirit of soul or dynamics but must be done with self-control so as not to lead to rudeness), sengguh (self-confident but without leading to arrogance) and ora mingkuh (strong-willed, unyielding and full of responsibility. However, it must be followed by efforts to build discipline for oneself (Department of Culture of the Special Province of Yogyakarta, 2014: 61) [8]. Likewise, Langen Mandra Wanara is not single dances but dances that feature many dancers by depicting certain types of characters through the embodiment of its figures, actually a brand a also presented their social life when they danced together and complemented each other because they come from among the people who prioritize living together in order to maintain harmony and balance in their social life. 
Throughout his journey, Langen Mandra Wanara grew to become a bridge between the majesty of the palace art style, which was coloured by the control of noble attitude and the simple yet straightforward folk art full of uplifting spirit. This combination gave birth to a classy art form and, at the same time, thick with a populist spirit. So, it is only natural that this art was trendy and favoured by the broader community in its time.

\section{CONCLUSION}

The research conclusion shows that in dancing Langen Mandra Wanara has a basic concept called the Joged Mataram philosophy. At the beginning of its development, the Langen Mandra Wanara performance was marked by the appearance of a large number of wanara (monkey) dancers. Unlike other arts displayed in the royal environment, Langen Mandra Wanara aims to provide entertainment to the public for free. In its development, Langen Mandra Wanara's performance declined due to the influence of the Dutch colonial economic situation. Currently, Langen Mandra Wanara shows tend to be concise and perform much shorter and involve fewer players. Thus, the production cost of court performing arts can be reduced much cheaper than before.

\section{References}

1. Kistanto, N. H. (2015). Tentang Konsep Kebudayaan. Sabda, 10(2), 1-11.

2. Berrell, M. (2021). National Culture and the Social Relations of Anywhere Working. In Blount, Y., \& Gloet, M. (Eds.), Anywhere Working and the Future of Work (pp. 23-59). IGI Global. http://doi:10.4018/978-1-7998-4159-3.ch002.

3. Çakir, A (1991). The Importance of the Protection of Traditional Dances. Studia Musicologica Academiae Scientiarum Hungaricae, 33(1-4), 295-299. Doi: $10.2307 / 902451$.

4. Jaeni. 2014. Kajian Seni Pertunjukan dalam Perspektif Komunikasi Seni. Bogor: IPB Press.

5. Sugiyono. 2013. Metode Penelitian Pendidikan Pendekatan Kuantitatif. Kualitatif, dan R\&D. Bandung.

6. Prabhawati (2020). Komunikasi Kontemporer: Dinamika Budaya, Jurnalisme dan Kehumas.

7. Kartodirdjo, Sartono. 1990. Pengantar Sejarah Indonesia Baru: Sejarah Pergerakan Nasional. Jakarta: PT Gramedia.

8. Bambang Pudjasworo. 2014. Opera Tari Jawa Gaya Yogyakarta Langen Mandra Wanara. Yogyakarta: Dinas Kebudayaan DIY.

9. Ben Soeharto. 1999. Langen Mandra Wanara: Sebuah Opera Jawa. Yogyakarta: Yayasan Untuk Indonesia.

10. Dewan Kesenian Propinsi DIY. 1981. Mengenal Tari Klasik Gaya Yogyakarta. Yogyakarta: Departemen P \& K.

11. Mulyatno, F. H., \& Soedarsono, R. M. (1997). Tari rakyat Jawa: Potensi seni pertunjukan wisata yang cukup besar. [Yogyakarta]: Universitas Gadjah Mada.

12. Oktariani, D., \& Istiandini, W. (2015). Analisis Struktur Gerak Tari Jepin Langkah Simpang Di Kota Pontianak Kalimantan Barat. Jurnal Pendidikan Dan Pembelajaran Khatulistiwa, 4(3). 